\title{
The Influence of the Digital Age on Early Childhood Education Based Characters
}

\author{
Alfirda Dewi Nugraheni \\ Universitas Negeri Semarang, Semarang, Indonesia \\ e-mail: alfirdadn@gmail.com
}

\begin{abstract}
The development of the digital era today certainly affects the development of psychology and behavior of early childhood so that the family is the main bastion in conducting good education and adverse effects caused by technological developments in this digital era. The rise of cases of immorality experienced by early childhood is influenced by digital development. The development of sophisticated technology has a positive and negative impact on the whole society. The digital world has a negative impact on moral development and character for early childhood if not supervised by parents. Cyberspace communication begins to open but communication in the real world closes, children tend to be personalized and anti-social. The etiquette and morals grown by parents fade away due to lack of direct communication with other people and social media watched by children does not show moral messages and examples to do good and polite towards others. But there is a positive impact in the digital world for early childhood, as a medium of learning that can show the same object with the original, the media to stimulate imagination and creativity, effective and efficient, and able to train the ability of motor, cognitive and language in children.
\end{abstract}

Keywords: digital era, early childhood, parents, character

\section{INTRODUCTION}

The digital age is closely linked to current technological developments, not just focusing on adults but also affecting the lives of young children. Supervision and provision of rules on children against the use of gadgets is very important in anticipation of incoming information. Parents are expected to always provide direction so that children can choose and enjoy information appropriate to their age. What children watch is very influential on moral development and character.

The formation of a child's personal character begins in the family because the child begins to interact with other people first in the family environment. Therefore, parents are the main shield for child development. Proper coaching and education should be given early on as the basis for character planting. The purpose of education is to produce a mature, intellectually, and spiritual human personality.

If a child from a child has been implanted politely and politely and moral values are always upheld it will affect the behavior in the future. Moral cultivation can not only occur in the family environment, but also within the community. Character formation can be through character that involves aspects of knowledge, feelings, and actions. The effect of character education on early childhood will cause maturity in processing emotions.

Educating children by utilizing technological sophistication is not a mistake that can directly recognize children so that children and parents do not stutter technology, but must be in accordance with the portion so that children do not become the gadget and internet addicts. In the digital world that has many positive and negative aspects. In the positive side of the digital world can be used as a medium of learning to stimulate the development of 
children's understanding of something, can also concretely abstract objects and media to train children's strategy in solving something. But the negative side of the digital world also threatens early childhood that can lead to addiction to gadgets, such as children who are addicted to youtube, video games and apps that attract interesting kids fun with gadgets and do not care about the environment even rarely to communicate and interact with others.

\section{DISCUSSION}

\subsection{Educate the character of early childhood}

In a large Indonesian dictionary, "character" is character, morality or character that distinguishes someone from others. Suyanto (2009) defines character as a way of thinking and behaving that characterizes each individual to live and work together well in the scope of family, society, nation, and State. A child of good character is a child that can make decisions and be ready to answer every consequence of the decisions he makes.

In character education (Lichnona: 1992) emphasizes the importance of three components of good character that is moral knowing, moral feeling and moral action. These three moral values ares important and necessary for early childhood to be able to understand, feel, and at the same time carry out the values of goodness.

Implanting character of early childhood should be gradual and through simple explanations of short stories and direct practice as examples so that children understand and capture the meaning of good character. By getting used to living with a good character then if a time the child did wrong or not in accordance with good behavior then in his heart very feel guilty, not calm and emerge a sense will not repeat the act again.

There are several kinds of characters that must be understood by early childhood is the character of human beings, the character of creatures other than humans (animals and plants) and characters against inanimate objects (environment and nature). Giving understanding to early childhood that loved and respect not only to fellow human beings but feeding animals, not torturing animals, watering plants, planting trees, not carelessly harvests and protecting the environment including commendable acts.

It can not be separated from parental parenting to educate and interact with the child, should not the parents give severe punishment to the child, if he is guilty in his consciousness he feels bad but there are willing to tell the truth and lie for fear of getting an unpleasant response from parents who led to punishment.

Rehner's research shows that a person's childhood experiences greatly affect the development of his personality (character and emotions). The study shows that parental care, either accepting or rejecting their children, will affect emotional development, social-cognitive behavior, health and psychological function as adults.

In this case the child accepted is a child who is given a love affair, both verbally (given the words of love and affection, words that give encouragement and praise), or physically (kisses, hugs, eye contact intimate).

Rehner's research shows that the parenting patterns that receive and make children feel loved, caring, valuable, and given support from their parents. This parenting pattern is very conducive to support the formation of a pro-social personality, confident, and independent but very concerned with the environment. Meanwhile, refusing parenting can create a sense of not acceptable, unloved, understated and even hated by his parents. Children who experience rejection from the tuany will become an independent person.

Parenting patterns of parents greatly affects even as the basis of planting character of early childhood both from how to educate, giving love, and patience in dealing with it.

A good parenting pattern can guide the child to the right path. Can be achieved in many ways, such as caea parents provide and apply rules to children, gift and punishment followed by advice, pointed automatically and open to choice.

Today's technological developments divert all aspects of human life. Gadgets that used to be tertiary need to became the primary requirement for the present because of their efficient and flexible use for all aspects. Such as sale and purchase transactions, entertainment, business, education, and so forth through applications that are easy to download.

\subsection{Early childhood and digital era}

Now this gadget is not just circulating among the people who need it, but the gadget is also circulating among young children. In fact, gadgets are not foreign goods for early childhood which in 
reality is not yet worth using gadgets (Prianggoro, Hasto.2014)

Sometimes also gadgets can be used as parents to divert the children so as not to interfere with the work of their parents so that parents provide facilities in the form of gadgets for their children (Widiawati \& Sugiman, 2014).

Actually, the sophistication of internet-based technology is also a lot of benefits for the family. Especially if introduced from an early age. Therefore, the role of parents is still very important to accompany their children when using the internet. Parents should consider taking into account the limitations of sites that may be visited. To make things easier, parents can suggest to their children to make a directory or search engine (search engine) special children, as a site that must be opened when first connected to the internet

In one study by Novitasari (2016) the use of gadgets are more fun than playing with peers. This is not separated by a variety of game applications contained in the gadget is considered more interesting and fun.

Parents who are busy with gadgets, sometimes forget their duties as the main stimulus of child language development that is used everyday.

Speech delays is one of the causes of developmental disorders in child language. According to Hurlock (in Anggraini 2011: 30) it is said that the rate of speech development of children is said to be late that age is the same and can be known from the accuracy of the use of the word. Unlike his peers, he is difficult to use words so that he can only communicate through gestures and speech styles. The cause of speech delay varies, one of the reasons is the use of gadgets.

Lately there are many cases of speech delay in early childhood. They experience speech delays until the age of 4 knows. This is unfortunate because their parents prefer gadgets rather than invite their friends to communicate and interact between children and parents, so children can not imitate something so they tend to be passive. From this passivity makes the child difficult to interact with others.

In addition to cases of speech delay there is a disturbance experienced by early childhood interference vision that symptoms are often blinking eyes that interfere with the concentration of children in observing something. In addition, not a few who complain of headaches due to gadget addiction. High levels of radiation result in anxiety in the elderly in the digital age today.
But if the use is already limited and supervised by parents then things that are not desirable will not happen. Parental supervision is a major factor in efforts to reduce the adverse effects of technology but can still take advantage of positive things such as supporting learning and improving the quality of children's understanding of something he has never known his form, as a medium of learning and train children to solve things with their own strategies .

Therefore, parents need to limit internet usage time. Make sure that the time spent using the internet does not absorb the time it should be used for other activities. Give certain pre-requisites to use the internet. For example, new children may use the internet if they have done their homework or schoolwork. There is no harm in also setting the hours of how children may use the internet and provide a limit on the amount of time. If necessary, use software that can limit their online time. Parents also need to introduce to children, educationalentertaiment sites (edutainment) or search engine special children.

Parental supervision is a key factor in reducing the adverse effects of technology but still being able to take advantage of it in a positive way. Thoughts of parents at this time also have experienced differences that are classified as far as the parents thought in earlier times. Then access in getting gadgets like tablets that exist in the current era of globalization, making the modern parents no longer need to buy a variety of toys for their children. Simply buy one tablet, which at this time the price is more affordable by the wider community. All sorts of games can be obtained easily when compared to the past full of traditional games. This situation makes children more pampered with all the sophistication of the gadget, where a single click can access a wide range of games and information that is current teraktual. Thus, the socialization of the child can be said to be less or not optimal with his peers and also lack of physical activity good for the mental and physical development of the child. When compared like two sides of a coin, this gadget has a positive impact as well as a negative impact on the child's development. Positive impact of the use of information and technology media is among others to facilitate a child in sharpening creativity and intelligence of children. The existence of a variety of digital applications such as coloring, learning to read, and writing letters of course give positive impact like a child's brain development. They do not need more time and energy to learn to read and write 
in books or papers, just use the tablet as a learning tool that is more fun.

\section{CONCLUSION}

Building a child's character is very important because the child is the next generation of this nation. Moral morals are increasingly worrisome, the movement of mental revolution as support for improving the moral and character of Indonesia in the future. Parental efforts to instill characters early on are an effective way to prevent children from moral crises and things that are forbidden by religion.

Educate children in the digital age by applying ways to monitor and allow children to play the applications contained in the gadget, but to provide time limits to prevent the occurrence of addictions that can cause bad things for early childhood development.

\section{Suggestion}

Character education should have been taught early because planting a good thing early on will have a good effect for the future. Parents who play an important role as a stimulus in the development of children should always provide examples and explanations of good deeds, do not let the child's character displaced by the digital era that has many obstacles to be faced. Attention, affection, and accompaniment from parents will save children from the negative impacts of gadgets and the digital world.

\section{REFERENCES}

[1] Astuti, Henny Puji. 2013. Perkembangan Anak Usia Dini 1. Yogyakarta:Deepuplish.

[2] Desmita. 2005. Psikologi Perkembangan. Bandung:Remaja Rosdakarya Offset.

[3] Anggraini, Wenty. 2011. Keterlambatan Bicara (Speech delay) pada Anak. (Study Kasus Anak Usia 5 Tahun). Skripsi. Universitas Negeri Semarang.

[4] Sudaryanti. 2017. Pentingnya Pendidikan Karakter Anak Usia Dini. Jurnal. Universitas Negeri Yogyakarta.

[5] Setiawan, Wawan. 2017. Era Digital dan Tantangannya. Seminar Nasional. Universitas Pendidikan 